Section 6

\title{
"Coal Investment and Long-Term Supply and Demand Outlook for Coal in the Asia-Pacific Region,"
}

by Charles J. Johnson, presented at the JAPAC International Symposium '97, February 19-20, 1997.

:STRIBUTION OF THIS DOCUMENT IS UNLMTIIED

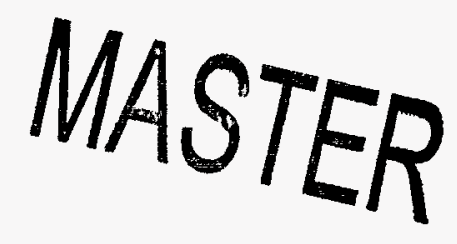

$$
\text { k }
$$

$$
\text { FCOB-94FEG33/3 }
$$




\title{
Cout $-9702115-2$
}

\section{Coal Investment and Long Term Supply and Demand Outlook}

\author{
for Coal in the Asia-Pacific Region
}

\author{
by \\ Charles J. Johnson, Ph.D. \\ Head, Coal and Environment Project \\ East-West Center \\ 1777 East-West Road \\ Honolulu, Hawaii, 96848
}

Tel: 8089447550

Fax: 8089447559

JAPAC International Symposium '97

February 19-20, 1997

Dai-ichi Hotel, Tokyo, Japan 


\section{DISCLAIMER}

This report was prepared as an account of work sponsored by an agency of the United States Government. Neither the United States Government nor any agency thereof, nor any of their employees, make any warranty, express or implied, or assumes any legal liability or responsibility for the accuracy, completeness, or usefulness of any information, apparatus, product, or process disclosed, or represents that its use would not infringe privately owned rights. Reference herein to any specific commercial product, process, or service by trade name, trademark, manufacturer, or otherwise does not necessarily constitute or imply its endorsement, recommendation, or favoring by the United States Government or any agency thereof. The views and opinions of authors expressed herein do not necessarily state or reflect those of the United States Government or any agency thereof. 


\section{DISCLAIMER}

Portions of this document may be illegible electronic image products. Images are produced from the best available original document. 


\section{Introduction}

We are just three short years away from the 21 st century, a century that will bring major changes in energy supply and demand that we cannot accurately predict. The theme of this symposium to look ahead almost a quarter century to 2020 gives us the freedom to speculate more than usual in our projections for coal. It is important to attempt to take a long term look into the future of coal and energy, so that we can begin to prepare for major changes on the horizon. However, it would be a mistake to believe that our crystal ball for making long term projections is accurate for 2020 . Hopefully it can suggest plausible changes that have long term strategic importance to Asia's coal sector.

This paper presents our medium scenario of long term projections of coal production, consumption, imports and exports in Asia. The second part of the paper examines the two major changes in Asia that could be most important to the long term role of coal. These include: (i) the impact of strict environmental legislation on energy and technology choices in Asia, and (ii) the increased role of the private sector in all aspects of coal in Asia.

\section{Regional Energy Trends}

Coal is Asia's primary energy source, in contrast to the dominant role of oil in the rest of the world. As shown in Figure 1, coal accounted for 46 percent of Asia's primary energy consumption in 1995, more than double the 20 percent share held by coal in the rest of the world. ${ }^{1}$ A key factor behind coal's dominance in Asia is China, which accounts for two-thirds of Asia's total coal consumption.

The second major difference in the energy mix is natural gas which accounts for only 9 percent in Asia, one-third of the 28 percent share in the rest of the world. The reasons for the small share held by natural gas in Asia are partially explained by the small reserves in Asia, the generally remote location of natural gas reserves, and lack of a regional pipeline distribution

\footnotetext{
${ }^{1}$ In this paper, Australia and New Zealand are included in Asia.
} 
system. $^{2}$ The combination of increasing attention to natural gas by governments and the private sector, and tougher environmental legislation, is expected to result in accelerated growth in the development and use of natural gas over the next two decades.

Total primary energy consumption in Asia is projected to increase by 250 to 300 percent over the 1995 to 2020 period. By 2020 Asia will be consuming as much primary energy as the rest of the world consumes today, or about 75 percent of total world primary energy consumption in 1995. Only under sound environmental and favorable investment policies can the energy demands of Asia in 2020 be met without a much more polluted Asian environment and greater risks of energy shortages.

\section{Asia's Growing Share of World Coal Consumption}

Figure 2 shows that Asia's share of world coal consumption almost doubled from 28 percent in 1980 to an estimated 53 percent in 1996, and is projected to reach 64 percent in 2020. Adjusting for the lower energy content of coal consumed in the two major consuming economies in Asia (China and India) reduces Asia's share of world coal consumption in terms of energy content in. 1995 to about $49-50$ percent. Thermal coal is projected to account for more than twothirds of the growth in coal consumption in Asia over the 1995 to 2020 period.

Figure 3 shows projected growth in coal consumption for the Asia-Pacific region over the 1995 to 2020 period. In our medium growth scenario, coal consumption is projected to increase from 1.9 billion tons in 1995 to 4.3 billion tons in 2020 -- an average growth rate of 3.3 percent per year. Under the high growth scenario, coal consumption increases to 5 billion tons by 2020, and under the low growth scenario, consumption increases to 3.2 billion tons in 2020 .

\section{Coal Imports}

Asian economies imported about 226 million tons of coal in 1995, and are projected to increase imports by an average of 10-13 million tons per year over the 1995 to 2020 period.

\footnotetext{
${ }^{2}$ I believe Asia's present natural gas reserves of about 9.5 trillion cubic meters can probably be doubled by 2020 , given increased attention to natural gas exploration, and the development of a pipeline distribution system in Asia.
} 
Figure 4 shows coal imports to Asian economies in 1995 with projected imports in 2020 . In 1995 , Japan was the leading coal importer at 122 million tons, and is projected to increase imports to about 150 million tons by about 2010 , before gradually decreasing to 125 million tons in 2020 .

The largest potential growth in imports is to India. However, India has a long history of restricting energy imports, and predicting future import levels remains highly speculative. Our medium estimate is that imports will grow from 11 million tons in 1995 to 90 million tons in 2020, the largest increase in imports among Asian economies.

The second largest importer in 1995, South Korea, is projected to be importing about 85 million tons (range 75 to 100 million tons) by 2020 , and may be a major importer of pipeline natural gas from Russia. If there is reunification of North and South Korea, total imports to the Korean Peninsula might reach 115 million tons by 2020 .

With respect to coal imports to China, the southern coastal areas of China have faced energy shortages throughout the 1990s, and prices of imported coal are similar to coal from inland coal deposits, when adjustment is made for the lower heat content of Chinese coals. Imports to China could range from 25 to 100 million tons in 2020 , with the medium growth scenario of 40 million tons shown in Figure 4. The medium projection of imports assumes that reforms in both the coal and railroad sectors will gradually improve the competitive position of Chinese coal shipments to central and southern coastal regions. Major new railroads, operated by private companies (perhaps under BOT arrangements), are expected to exist in China by 2010. Failure to achieve major reforms in China's rail transport sector could lead to Chinese coal imports of 75-100 million tons by 2020 .

The Philippines and Thailand are projected to use less coal than previously expected, owing to greater use of natural gas. Pakistan's coal imports are projected to be less than previously expected due to greater use of natural gas and domestic coal production. North Korean projections are little more than guesses; however, the economy is likely to move to open door investment and trade policies, like Vietnam and China, or unify with South Korea within two decades. Much of North Korea's anthracite reserves may not be economic under open market conditions. 


\section{Asia-Pacific Coal Production}

Asia-Pacific coal production closely parallels consumption, and the percentage of coal imported to the region is likely to remain the same or decrease over the next two decades. The reasons are the shift to a higher percentage of lower price thermal coal and lower price coking coals favors Asian over North American supplies. The three factors favoring Asian coal supplies for Asian markets are: (i) Asia's location far from major coal suppliers in North and South America, (ii) large coal reserves within Asia, and (3) a generally favorable investment climate in Asia that ensures timely expansions of coal capacity. China and India are projected to account for over 80 percent of the total growth in production in the Asia-Pacific region.

China accounts for 70 percent of the region's coal production. Recently released numbers indicate a surge in production over the past year to at least 1.36 billion tons in 1996 . The production in 2000 is likely to be closer to 1.5 billion tons or 100 million tons higher than the Chinese government's planned production of 1.4 billion tons in 2000 . The government has recently revised its 2000 projections to 1.45 billion tons. By 2020 China's coal production is projected to more than double to 2.5 to 3.0 billion tons per year.

\section{Coal Exports}

Most Asian economies have some coal resources, but only three economies are likely to increase exports by more than 10 million tons per year over the next two decades. As shown in Figure 5, Australia, China, and Indonesia are projected to dominate Asia-Pacific coal exports over the 1995-2020 period.

Australia's dominant export position is being challenged in the short term by growing exports from China and Indonesia, Australia is projected to continue to account for about twothirds of Asia's coal exports over the next two decades. Australia's share of exports may dip to about 65 percent over the next $5-10$ years, before climbing to over 70 percent by 2020 when its coal exports are projected to reach 300 to 350 million tons. Australia's favorable investment, its high quality coal reserves within $300 \mathrm{~km}$ of deepwater ports, and high quality infrastructure and modern mining practices support the conclusion that Australia can double its exports over the next two decades. 
China's major coal reserves are located inland about $1000 \mathrm{~km}$ from the coast (in Shanxi and Inner Mongolia), and coal on average is shipped about 600 kilometers to markets in China. Coal accounts for 43 percent of total rail transport tonnage, and is the leading cause of rail congestion in China. Major reforms are under way in China's coal industry to improve its efficiency. China is able to increase exports by about 2 million tons per year, and is unlikely to meet its target of 50 million by 2000 . Exports are expected to continue to increase by 1-3 million tons per year and reach 60-90 million tons in 2020. Net exports after deduction of imports are not expected to exceed 40 million tons per year over the 1995 to 2020 period.

Indonesia has some of Asia's lowest sulfur and lowest cost reserves on Kalimantan, but limited reported amounts of high energy content bituminous coal. Exports have increased rapidly from 4 million tons in 1990 to about 36 million tons in 1996, and are projected to increase to about 60 million tons by 2005 . They will then level off or decline, as the expected rapid growth in Indonesian coal consumption exceeds the growth in production. Government projections of future coal consumption in Indonesia are believed to be optimistic, and a more moderate growth rate in domestic coal consumption is assumed. Indonesia's large natural gas reserves are expected to be highly competitive with coal for electricity generation, particularly on heavily populated and polluted Java.

\section{Asia Shifts to Stricter Environmental Legislation}

The heavy reliance on coal in Asia has resulted in high levels of coal-related pollution in a number of Asian economies. China, which accounts for about two-thirds of Asia's coal consumption, also accounts for at least two-thirds of Asia's $\mathrm{SO}_{2}$ emissions. After decades of heavy emphasis on economic growth, and too little attention to the environment in some Asian economies, a better balance of economic and environmental goals is coming to Asia. In 1996, the APEC Experts' Group on Clean Fossil Energy completed a survey among APEC member economies of their emissions regulations for coal-fueled power plants. The survey reveals a major shift among all eight Asian economies to more stringent SO2 emissions limits in the 1990s.

With the notable exception of Japan, only a small percentage of coal-fired power plants in Asia have $\mathrm{SO} 2$ control technologies. In addition, most Asian coal is relatively low in sulfur, typically 0.7-1.2 percent, and internationally traded thermal coal in Asia typically contains $0.5-0.7$ 
percent sulfur. The, availability of abundant low sulfur coal reserves and supplies in Asia suggest a gradual and selective introduction of $\mathrm{SO}_{2}$ control technologies. However, as discussed in this section, trends in environmental legsiation are expected to accelerate the introduction of $\mathrm{SO}_{2}$ control technologies.

$\mathrm{SO} 2$ control technologies are installed in response to environmental legislation restricting sulfur emissions to levels that cannot be met by burning low sulfur coal. Examination of the trends in environmental legislation provides insights into when utilities are likely to install $\mathrm{SO}_{2}$ control technologies or switch to cleaner fuels. Most national emission standards in Asia are based on $\mathrm{SO} 2$ emissions measured in $\mathrm{mg} / \mathrm{m} 3$ or $\mathrm{ppm}$. Emission standards in eight Asian economies were converted to the estimated sulfur content in coal that would meet the emissions standards (compliance coal). Although the conversions are approximate, they provide useful insights about the future trend toward $\mathrm{SO} 2$ control technologies and fuel switching.

Figure 6 shows the "approximate" maximum sulfur contents of compliance coal required to meet existing and planned emission limits in the eight Asian economies. In Figure 6, the year that the emission limit takes effect is shown for each economy. None of the eight Asian economies allows burning of coal containing more than 1.0 percent sulfur. Japan and Hong Kong have very strict limits equivalent to 0.1 percent sulfur coal for new plants in Hong Kong and all plants in Japan. Indonesia, South Korea, and the Philippines had limits for compliance coal in the 0.5 to 0.75 percent sulfur range in 1996. However, they will tighten the limits by 2000 to lower the limit to 0.35 to 0.4 percent. The limit of about 0.72 sulfur coal for Chinese Taipei is misleading, because all new coal-fired plants must install $\mathrm{SO}_{2}$ control technology. Thailand's limit of about 0.47 percent sulfur coal can be met by low sulfur coal imports from Indonesia and Australia.

From a regional environmental perspective, China's approach to controlling coal related pollution is of great importance. Effective environmental action in China is essential to halt the long term increase in coal-related pollution in Asia. Although China is unlikely to stop the growth in coal-related pollution for at least a decade, China is taking serious steps to slow the growth in pollution. China passed legislation in 1996 that requires new coal-fired plants built after 1996 to 
install $\mathrm{SO}_{2}$ control equipment when coal contains more than 1.0 percent sulfur. ${ }^{3}$ This legislation implies that a different China may emerge in the first quarter of the 21 st century. In addition to national legislation, stricter environmental legislation is being passed at the province and city level - such as in the Pearl River Delta in Guangdong Province, and Beijing. Although, full enforcement of tighter environmental legislation in China may take many years, the shift is expected to have a far reaching impact on the environment, use of clean coal technologies, and the introduction of natural gas and coal bed methane.

Tighter $\mathrm{SO} 2$ emissions limits are moving to 0.4 (or less) percent sulfur compliance coal by the year 2000 in seven of the eight Asian economies surveyed. Even, in China, a number of high growth coastal areas are moving toward tight $\mathrm{SO}_{2}$ emissions limits that will necessitate $\mathrm{SO}_{2}$ control technologies or natural gas in future plants. The conclusion is that within a decade the majority of new coal-fired power plants in Asia, fueled with imported coal, will include $\mathrm{SO}_{2}$ control technologies (mostly flue gas desulfurization - FGD). Advanced $\mathrm{SO}_{2}$ control systems add roughly $\$ 0.01$ per $\mathrm{kWh}$ to the cost of generating electricity and improve the competitive position of cleaner fuels -- low sulfur compliance coal, natural gas, and coalbed methane. ${ }^{4}$

\section{Natural Gas Challenges Coal in the Power Sector}

The trend in prices of internationally traded coal has been generally downward over the 1980-1996 period, and is not projected to increase in constant dollar terms over the next two decades. ${ }^{5}$ In 1996, on the basis of the same energy content, thermal coal imports to Asia cost about 40 percent of the cost of LNG, 50-60 percent of the cost of pipeline gas, and 65 percent of the cost of fuel oil. However, such comparisons of the energy content of different fuels are misleading, because they do not reflect the total costs to the consumer. For electricity generation,

\footnotetext{
${ }^{3}$ The new Chinese regulations state that for new plants burning more than 1.0 percent sulfur coal, $\mathrm{SO}_{2}$ control equipment must be added that rectuces emissions to the equivalent to 0.6 percent sulfur coal. This is equivalent to having two standards, one at 1.0 percent and one at 0.6 percent sulfur. This contradiction and a number of other uncertainties, suggest there will be modification to these regulations.

${ }^{4}$ The potential of coalbed methane from major coal basins in China and India appears large, and may exceed the proven natural gas reserves of these two countries.

${ }^{5}$ A price premium could develop for very low sulfur thermal coal (less than about 0.4 percent sulfur).
} 
the economics of the power plant need to include differences in capital costs, emissions control equipment, and thermal efficiencies.

A common comparison among fuels is to estimate the break-even price of competing fuels at the power plant. The break-even price is the maximum price that a fuel can sell for and compete with an alternative fuel. Table 1 shows the plausible "break-even price" of coal with pipeline-natural gas at $\$ 3.50$ per million Btu (MBtu) and LNG at $\$ 4.30 / \mathrm{MBtu}$ (including regasification) for different coal-fired power plant technologies in 1991, 1996, and 2005. Table 2 shows the assumptions for the power plant models. The cost estimates are hypothetical, but plausible, assuming the decisions to construct new plants were made in 1991; 1996, and 2005. ${ }^{6}$ The cost figures for 1991 are in current dollars (not adjusted for inflation), and the costs for 1996 and 2005 are in constant 1996 dollars. $^{7}$

The long term c.if. price of imported thermal coal in Asia is projected to range from about $\$ 41$ to $\$ 48$ per ton. A long term price of $\$ 44$ per ton is assumed in the analysis of the break-even coal prices in Table 1. The conclusions from Table 1 are as follows:

- A coal-fired PC plant without FGD, using imported coal, is competitive with LNG in 1991, 1996, and 2005, and competitive with pipeline natural gas in 1991 and 1996, but not 2005.

- A coal-fired PC plant with FGD, using imported coal, is competitive with LNG for 1991 and 1996 , but not 2005; it is not competitive with pipeline natural gas for any year.

- Integrated gasification combined-cycle (IGCC) is slightly more expensive than a coal-fired plant with FGD by 2005 , but is not competitive with natural gas or LNG in the options examined.

\footnotetext{
${ }^{6}$ The power plant costs would apply to many locations in Asia, but would not apply to Japan where costs are much higher.

${ }^{7}$ It is recognized that mixing current and constant dollar figure in a table can be misleading about the constant dollar prices for 1991. However, costs in Table 2 are believed to be useful because most observers are thinking in current dollar terms for 1991 and 1996 plant costs.
} 
The above results need to be used with caution, because small changes in assumptions could reverse some of the conclusions. The main observation is that natural gas is becoming a serious challenger to coal-fired plants with FGD and imported coal.

IGCC technology is not competitive for electricity generation with any of the coal or natural gas technology options shown in Tables 1 and 2. However, IGCC technologies are still evolving, and by 2005 or 2010 may prove to be more competitive than indicated in Table 1 . IGCC has two important advantages over conventional coal technologies: (i) it produces gas suitable for combined-cycle electricity generating plants and as a feedstock for chemicals; plus (ii) its higher efficiencies will result in lower $\mathrm{CO}_{2}$ emissions than conventional coal-fired plants. IGCC's commercial prospects are enhanced by recent advances in gas turbine technologies (higher thermal efficiencies and lower capital costs), because these same technologies are an integral part of an IGCC system. ${ }^{8}$

The conclusion is that, where sufficient pipeline natural gas is available at $\$ 3.50 / \mathrm{MBtu}$ or less, it will take away markets depending on coal imports. Increasingly, LNG may penetrate markets previously dominated by coal imports. Natural gas and LNG are not competitive with low cost coal supplies within coal mining areas, but are expected to penetrate markets previously dominated by medium- to high-price domestic coal.

\section{Regional Natural Gas Pipelines}

Asia has less than 7 percent of the world's natural gas reserves and 10 percent of world production. The most important factor limiting natural gas use in Asia is the lack of a natural gas distribution system. There is no regional natural gas network, although regional pipelines have been extensively examined. The combination of the growing wealth of most Asian economies, and the trend toward strict emissions legislation related to coal burning, is projected to result in a number of major regional natural gas pipelines by 2020 . There is likely to be a pipeline across China (from Xianjiang to the coastal provinces); a pipeline from Russia to the Asia-Pacific rim; pipelines from Indonesia and Malaysia into Southeast Asia, and from Vietnam to Thailand and or southeastern China. Asia's present natural gas reserves of about 9.5 trillion cubic meters can

\footnotetext{
${ }^{8}$ Abundant supplies of heavy oil and petroleum coke are good feedstocks for IGCCs, and the development of IGCCs could also be accompanied by an increase in petroleum product use in the power sector.
} 
probably be increased to $15-20$ trillion cubic meters by 2020 with accelerated natural gas exploration, and the development of a pipeline distribution system in Asia.

\section{Coalbed Methane}

A new fuel is just emerging as a potential important clean fuel for the first two decades of the 21 st century. Coalbed methane, historically recovered from coal mines to reduce the danger of methane explosions, is now viewed as an important new source of methane (natural gas). China and India are the two largest candidates for coalbed methane production in Asia. China has an estimated 30-35 trillion cubic meters of coalbed methane resources, compared with under 1.5 trillion cubic meters of natural gas reserves. If only 5 percent of China's coalbed methane potential proves to be commercial, it would equal China's natural gas reserves. High quality coalbed methane can be injected into natural gas pipelines -- a prime possibility is to inject coalbed methane_into the natural gas pipeline under construction from Shaanxi Province, across the coalbed rich coal fields of Shanxi, to Beijing.

Under favorable government policies, and active private sector investments in coalbed methane exploration and development, production levels of 1.5-3 trillion cubic feet per year might be achieved in Asia by 2020. This is sufficient to meet the fuel needs of $30-60 \mathrm{GW}$ of power plant capacity if all of the coalbed methane was used for electricity generation. In the case of China, it is more likely that most natural gas and coalbed methane will be used for industrial users (excluding electricity) and the domestic (household) sector.

\section{Private Sector Coal Mine Investments in Asia}

For the medium growth scenario for coal, new mine capacity to 2020 could cost $\$ 150-200$ billion in constant 1996 dollars, excluding transportation infrastructure and end use investments (power plants, etc.). In addition, ongoing capital improvements to existing coal mines could add another $\$ 100$ billion in investments to 2020 . Therefore, total direct investments in coal mines in Asia to 2020 could be $\$ 250$ to $\$ 300$ billion in constant 1996 dollars. The multilateral lending banks (World Bank and Asian Development Bank) lend less than $\$ 8$ billion per year to all infrastructure in Asia - less than 5 percent of infrastructure investments requirements. Neither the World Bank or the Asian Development Banks is likely to become a major lender to a coal 
mining project. The conclusion is that most funds for coal mine expansions will come from governments, and increasingly from private sector investments, and that multilateral banks will play only a minor role in lending for mine developments in Asia.

\section{Conclusions}

In conclusion, coal consumption and trade in the Asia-Pacific region are likely to grow at 3.0 to 3.6 percent per year to 2020. Australia, China, and Indonesia will dominate the Asian coal export market, and account for most of the growth in imports to Asian economies over the next two decades.

The move across Asia to tighter $\mathrm{SO}_{2}$ emissions regulations and improvements in combined-cycle gas turbine technologies are improving the competitive position of natural gas with coal-fired power plants. These improvements are expected to slow the growth in thermal coal trade in Asia over the 1995-2020 period. Evolving IGCC technologies are expected to become competitive during the first decade of the 21 st century, and are likely to capture a significant share of the power generation market after 2005 or 2010 .

The role of natural gas and coalbed methane is projected to become increasingly important in Asia, particularly after 2010 when one or more major regional natural gas pipelines are completed.

The most important factor influencing the long term supply and demand for coal in Asia is coal's ability to compete with alternative fuels as environmental standards are tightened across Asia. Coal consumption will more than double by 2020 under the three scenarios examined. However, by 2020 the following "gas fuels" could become the largest growth area among fuels in Asia: LNG, natural gas delivered by a regional pipeline system, gasification of coal (IGCCs) for the power, industrial and household sectors, and coalbed methane for the industrial and household sectors. Investment requirements in coal mining are expected to be met increasingly by the private sector, with a declining role of government funding, and only limited lending from the World Bank and Asian Development Bank. An increasingly important role for multilateral lending institutions will be to increase loans to the energy sector that reduce coal-related pollution and increase energy efficiencies. 

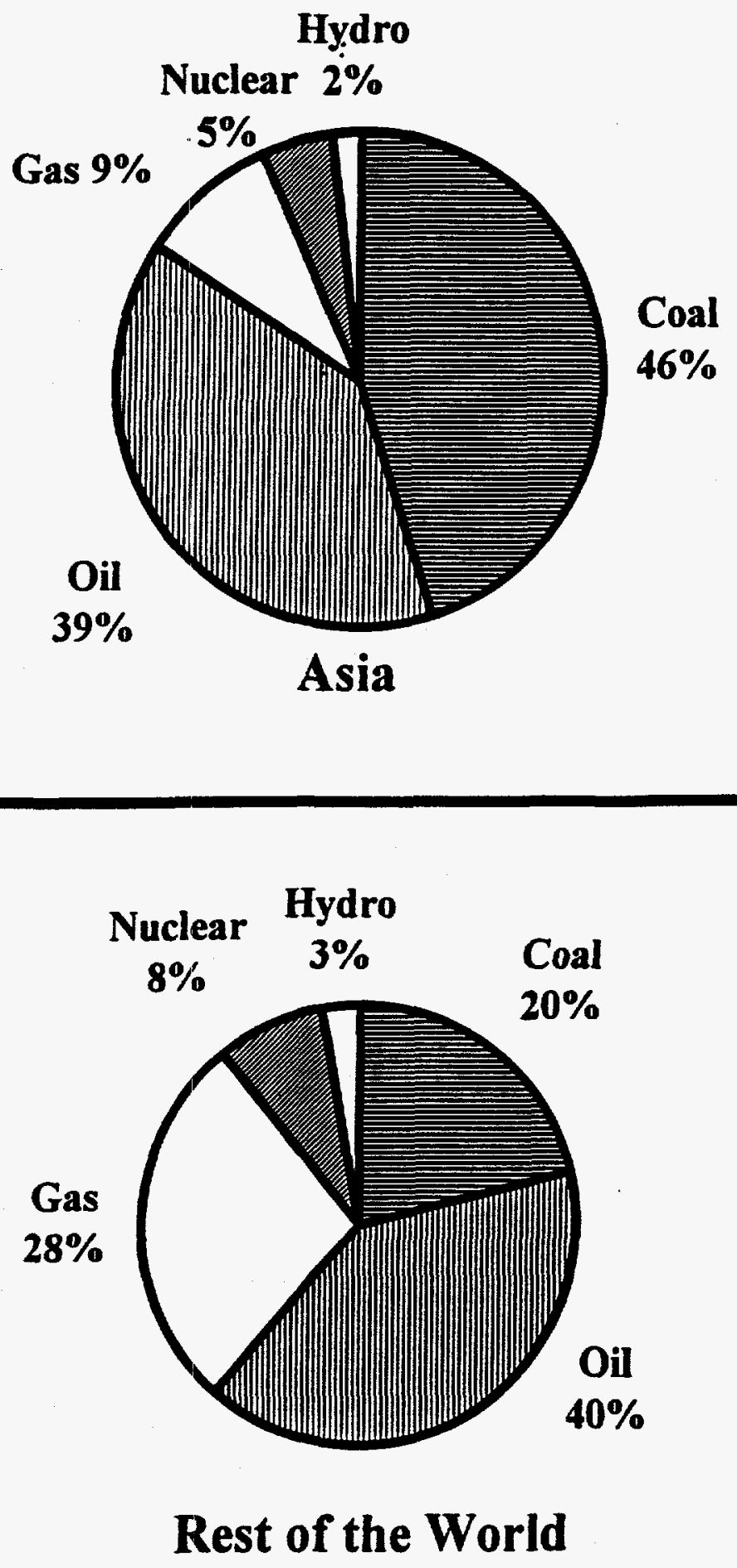

Figure 1: Primary energy shares in Asia and the rest of the world in 1995

Source: BP 1996 


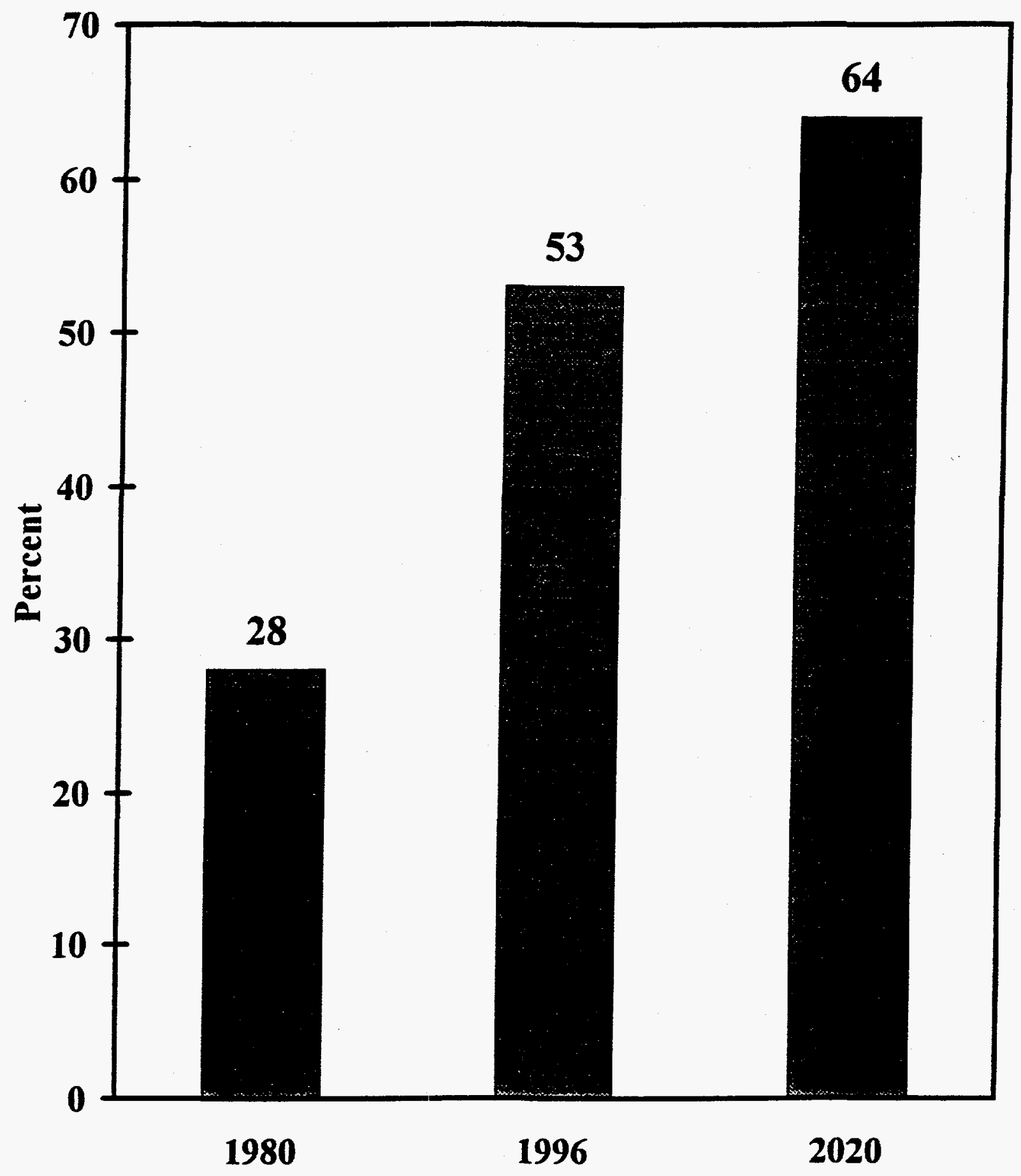

Figure 2. Asia's growing share of world coal consumption 


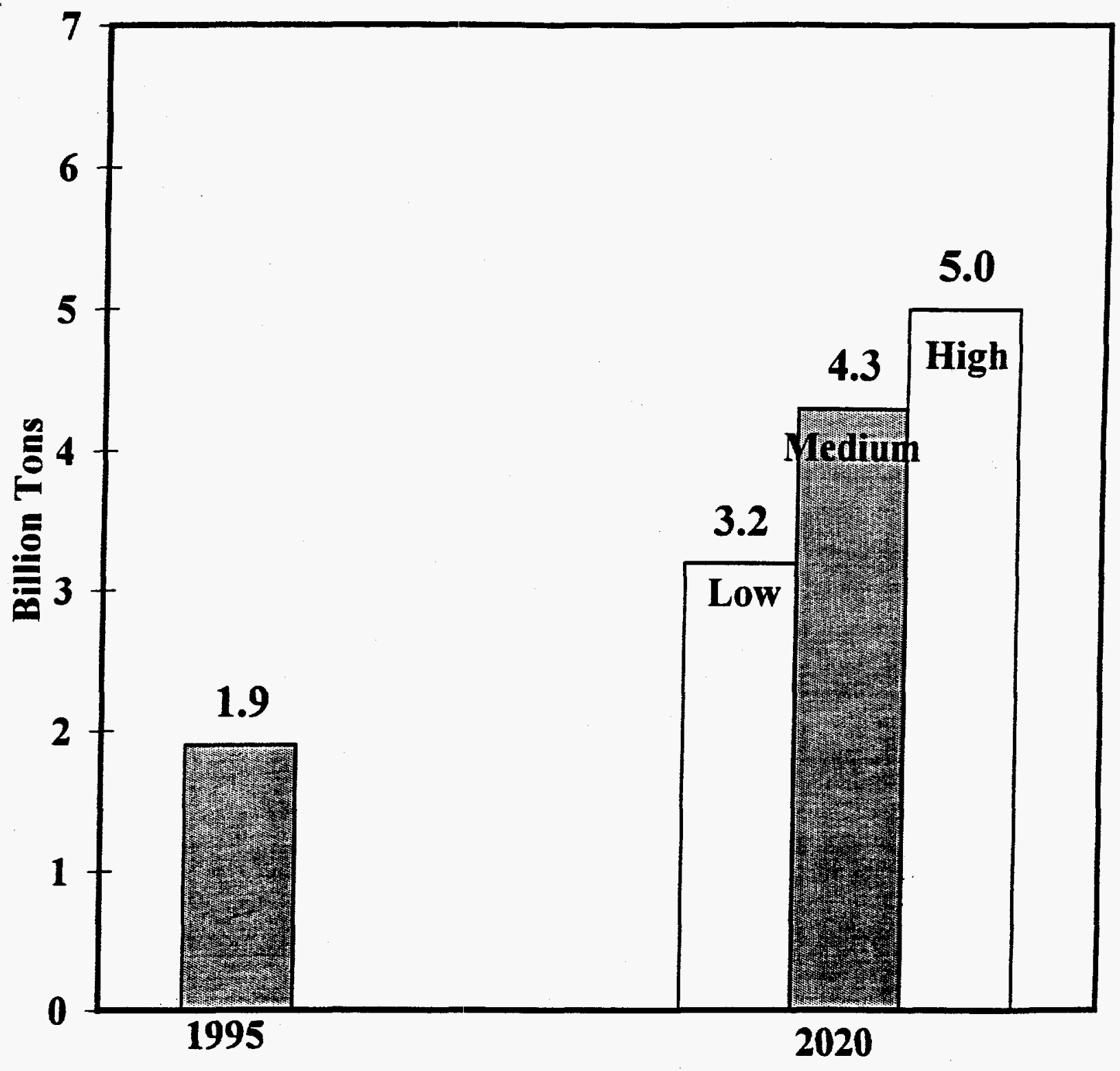

Figure 3. Coal consumption in 1995 and projected imports in 2020 in the Asia-Pacific region 


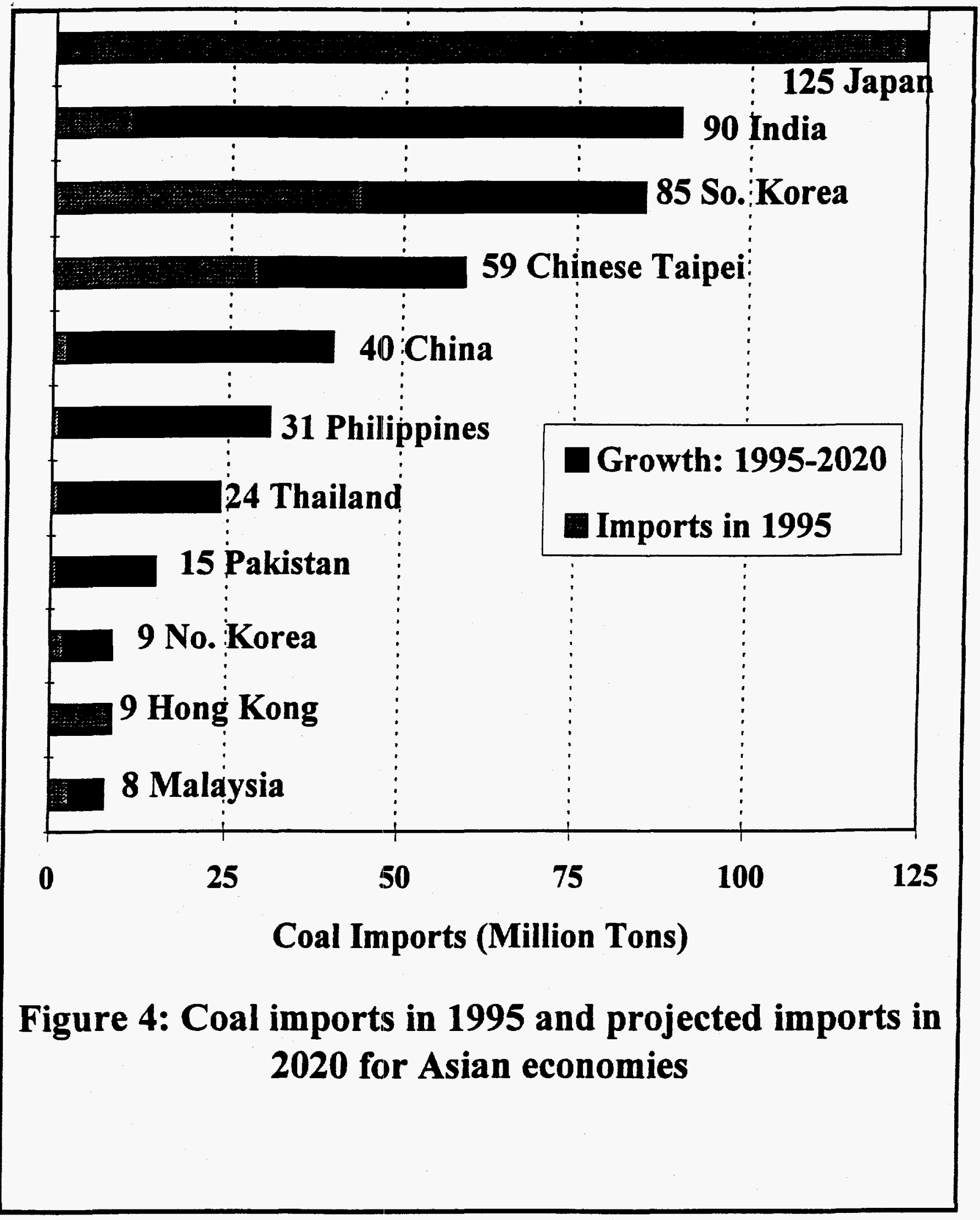




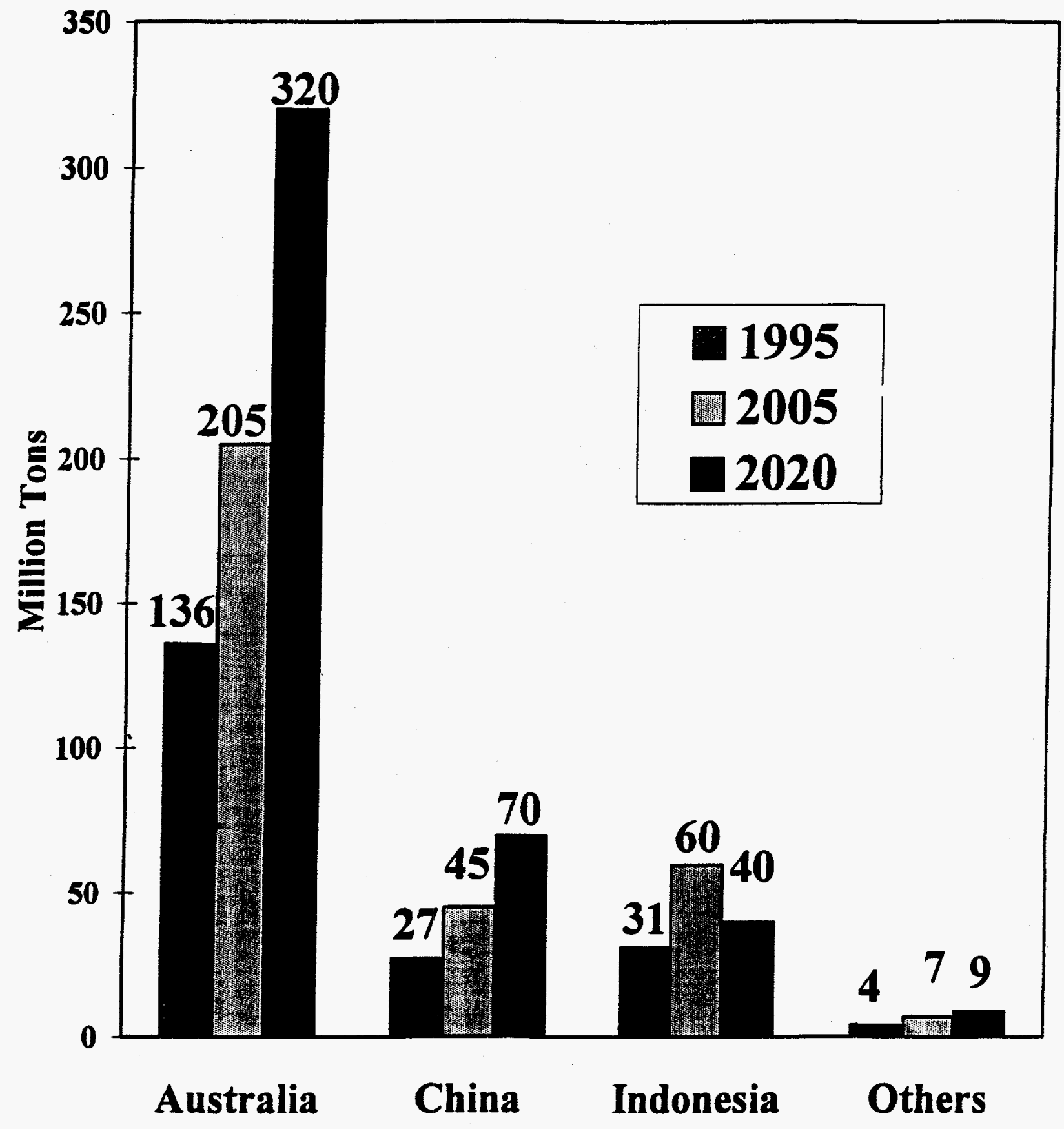

Figure 5: Coal Exports from Asia-Pacific Economies, 1995-2020 


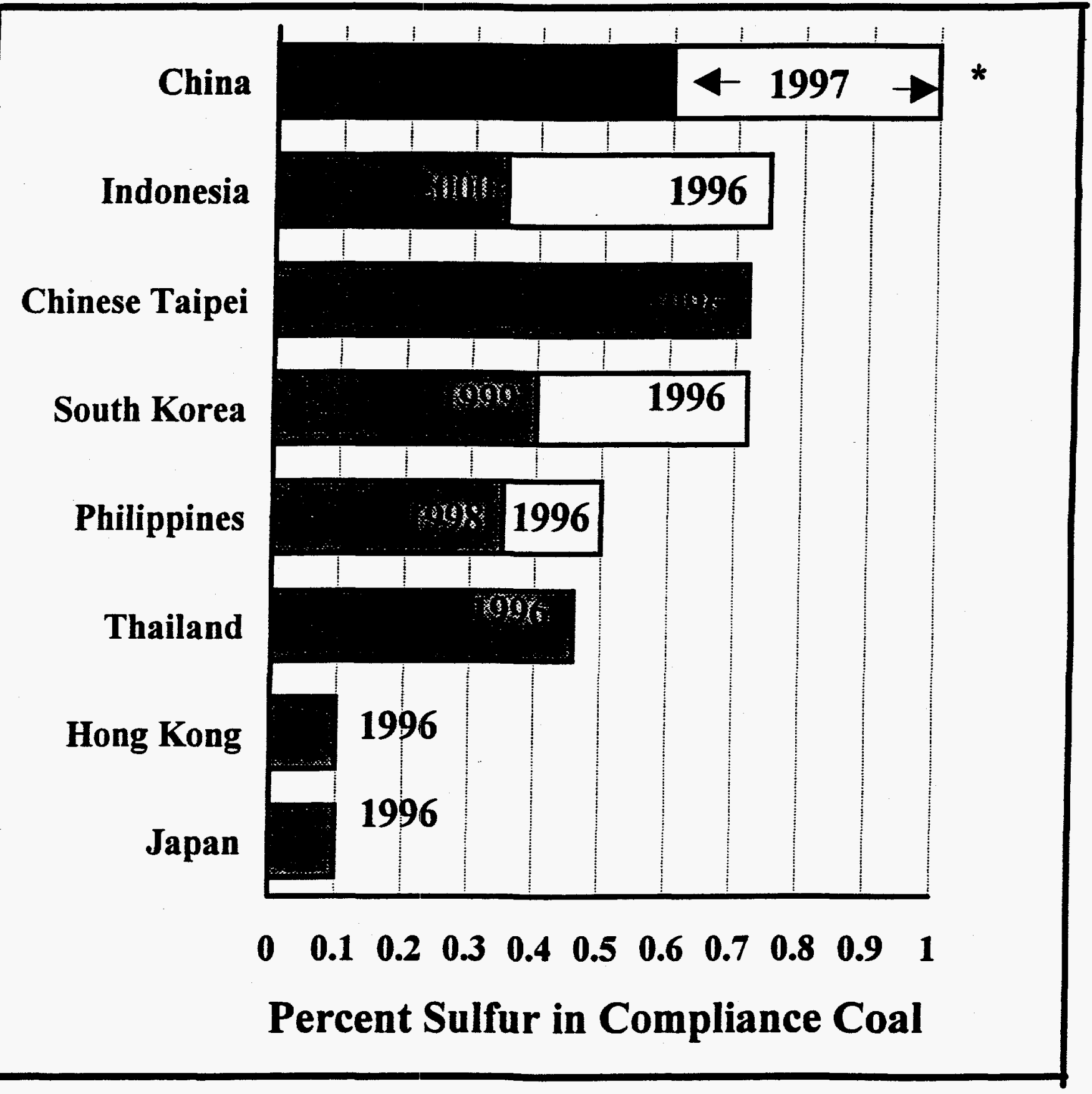

\section{Figure 6. Estimated maximum percent sulfur in coal that will meet emissions standards in eight Asian economies}

* China has effectively two standards for new plants: up to 1.0 percent coal can be burned in new plants, but above 1.0 percent coal requires $\mathrm{SO}_{2}$ control to reduce emissions to the equivalent of 0.6 percent sulfur. 


\section{Table 1}

Breakeven Prices for Coal-Fired Power Plant Technology Options with Pipeline Natural Gas and LNG

(A) Breakeven coal price (\$/t) with pipeline natural gas at $\$ 3.50 / \mathrm{MBtu}$ in a combined-cycle plant

\begin{tabular}{|l|c|c|c|}
\hline Coal Plant Technology & 1991 & 1996 & 2005 \\
\hline Coal-fired PC (no FGD) & 47 & 45 & 36 \\
\hline Coal-fired PC (+ FGD) & 28 & 31 & 24 \\
\hline IGCC & n.a & 6 & 19 \\
\hline
\end{tabular}

(B) Breakeven coal price ( $\$ / t)$ with LNG at $\$ 4.30 / \mathrm{MBtu}$ in a combined-cycle plant

\begin{tabular}{|l|c|c|c|}
\hline Coal Plant Technology & 1991 & 1996 & 2005 \\
\hline Coal-fired PC (no FGD) & 64 & 61 & 52 \\
\hline Coal-fired PC (+ FGD) & 44 & 47 & 39 \\
\hline IGCC & n.a & 25 & 38 \\
\hline
\end{tabular}




\section{Table 2 \\ Cost Assumptions for Power Plant Technology Options}

\begin{tabular}{|c|c|c|c|c|}
\hline Technology & Units & 1991 & 1996 & 2005 \\
\hline \multicolumn{5}{|c|}{ Coal-Fired PC (no FGD) } \\
\hline Capital Cost & $\$ / k W$ & 1100 & 1050 & 1025 \\
\hline O \& M ( excl. fuel) & $\$ / k W h$ & 0.0061 & 0.0061 & 0.0061 \\
\hline Fuel Efficiency & Percent & 36.5 & 37.6 & 37.5 \\
\hline \multicolumn{5}{|c|}{ Coal-Fired PC (+ FGD) } \\
\hline Capital Cost & $\$ / \mathrm{kW}$ & 1275 & 1125 & 1100 \\
\hline O \& M ( excl. fuel) & $\$ / k W h$ & 0.0086 & 0.0086 & 0.0086 \\
\hline Fuel Efficiency & Percent & 35.5 & 36.3 & 36.7 \\
\hline \multicolumn{5}{|l|}{$\underline{\text { IGCC }}$} \\
\hline Capital Cost & $\$ / \mathrm{kW}$ & - & 1475 & 1175 \\
\hline O \& M ( excl. fuel) & $\$ / k W h$ & -- & 0.01 & 0.01 \\
\hline Fuel Efficiency & Percent & -- & 43.5 & 46.5 \\
\hline \multicolumn{5}{|c|}{ Combined-Cvcle Natural Gas } \\
\hline Capital Cost & $\$ / \mathrm{kW}$ & 800 & 725 & 650 \\
\hline O \& M ( excl. fuel) & $\$ / k W h$ & 0.0042 & 0.0042 & 0.0042 \\
\hline Fuel Efficiency & Percent & 46 & 47.5 & 51 \\
\hline
\end{tabular}

Note: All plants are assumed to have a load factor of 75 percent, an operating life of 25 years and a discounted rate of return on capital of 15 percent. Costs and financing arrangements vary considerably between projects and can have a substantial impact on the relative economics of different plant and fuel options. 